\title{
European trends in spatial mobility
}

\author{
DALLEN J. TIMOTHY ${ }^{1}$ and GÁBOR MICHALKÓ ${ }^{2}$
}

From a Eurocentric point of view, Europe has long functioned as the caput mundi of human mobility - a home and destination for hunters and gatherers, conquerors, colonizers, learners and scientists, pilgrims, tourists, emigrants and immigrants. From Europe's ancient frontiers and marches to today's precisely delineated and demarcated state boundaries, borders have long affected economic, social, military and political relations between ancient and modern states. During the past half century, however, globalization processes, including the supra-nationalization of Europe, have changed inter-state relations and human mobilities perhaps more than any other force in recent history.

These geopolitical vicissitudes have had a clear and concise 'de-bordering' effect, particularly since the Schengen Convention of 1990, which paved the way for the abolishment of intra-Schengen Area border inspections and the establishment of a shared visa regime (ТімотнY, D.J. 2001; TімотнY, D.J. and SAARinen, J. 2013). This de-bordering process has accelerated migration to Europe and between states within Europe, as well as stimulated tourism as an economic growth engine (ETzo, I. et al. 2014).

Because of its relative location, high standard of living, colonial history, and generous immigrant and refugee benefits, Europe has become a magnet for migrants from Africa and the Middle East across the Mediterranean Sea and through Asia Minor. This pattern of migration, especially since 2013 , has generated a great deal of pressure on Europe, which has flared many debates and spurred legal challenges continent-wide. While much public opinion, thanks largely to the media, concentrates on arrivals from Africa, the Middle East and Asia, intra-regional migration in Europe receives much less media attention.

There are many migratory flows between European countries in the form of amenity (quality-of-life) migration (GosNelL, H. and Aвrams, J. 2011), labour migration (Andrijasevic, R. and Sacchetto, D. 2016), student migration (Wells, A. 2014) and return migration (ILLÉs, S. 2015). Together, these form a relatively new and dynamic phenomenon enabled and encouraged by the establishment of the European Union and its associated 'freedom of movement' treaties, such as the 1985 Schengen Agreement and the 1990 Schengen Convention. Simultaneously, the entry of Europe's former socialist states into the EU and Schengen Area, and the concurrent permeation of these countries' citizens into the Western European labour market, has significantly broadened the scope and scale of intra-European migration (ANDRIJASEVIC, R. and SACchetTo, D. 2016), just as economic hardships in Mediterranean Europe have induced large-scale migrations northward.

Besides migration, tourism is one of the most widely researched configurations of cross-border human mobility. Migration and tourism share a number of symbiotic relationships, which result in several manifestations of tourism supply and demand (HALL, C.M. and Williams, A. 2002; Coles, T.E. and TiмотнY, D.J. 2004; Illés, S. and Michalkó, G. 2008; Lew, A.A. et al. 2015). Europe has

\footnotetext{
${ }^{1}$ School of Community Resources and Development, Arizona State University, 411 N. Central Avenue, Suite 550, Phoenix, Arizona, USA 85004. E-mail: dtimothy@asu.edu

${ }^{2}$ Geographical Institute, Research Centre for Astronomy and Earth Sciences, Hungarian Academy of Sciences, H-1112 Budapest, Budaörsi út 45; Department of Tourism, Corvinus University of Budapest. H-1093 Budapest, Fővám tér 8. E-mail: michalko.gabor@csfk.mta.hu
} 
been the most visited region in the world for many decades, and the connections between tourism and migration are very apparent. First, migration stimulates a wide range of tourism types, including 'visiting friends and relatives' (VFR) tourism, second-home tourism, religious tourism, diaspora tourism and roots tourism. Secondly, it provides a heritage resource base for tourism, including ethnic neighbourhoods, cultural landscapes, heritage cuisines and ethnic foods, festivals, and other culture-based resources (Coles, T.E. and Тімотну, D.J. 2004). Third, one of the most salient reasons people migrate abroad is to seek work in the tourism sector. Labour migrants are eager to find employment and often provide affordable labour for the service industries, including tourism. Finally, there is a long history of people being attracted to foreign locales (e.g. the UK to Spain) for entrepreneurial reasons, including setting up hospitality-related businesses.

Migration and tourism are two of the most salient manifestations of human mobility, but so are short-distance and same-day crossborder trade, work, healthcare and shopping trips (Michalкó, G. and Tıмотну, D.J. 2001). As noted earlier, the topic of mobility is one of the most researched contemporary themes in human geography (Merriman, P. 2009; Staeheli, L.A. 2016). There are mounting pressures associated with migration to and within Europe, growing trends in cross-border tourism and trans-boundary labour, increasing supranational trade and cross-frontier utilitarian shopping, a need for more cost-effective and convenient forms of transportation (e.g. ride sharing), and the creation of new spaces and places of mobility. Therefore, it is incumbent upon geographers and other social scientists to continue examining and debating the spatial and regional dimensions of human mobility and to disseminate knowledge through publications, scientific workshops and conferences.

This special issue of the Hungarian Geographical Bulletin does just that by focusing on spatial mobility trends in Europe. This issue is comprised of papers presented in the 'Globility' sessions at the 2015 EUGEO Congress in Budapest, Hungary (Photo 1).

With the support of the International Geographical Union (IGU), the Commission on Global Change and Human Mobility ('Globility'), was founded in 2000 to specialize in human movement in border areas and hu-

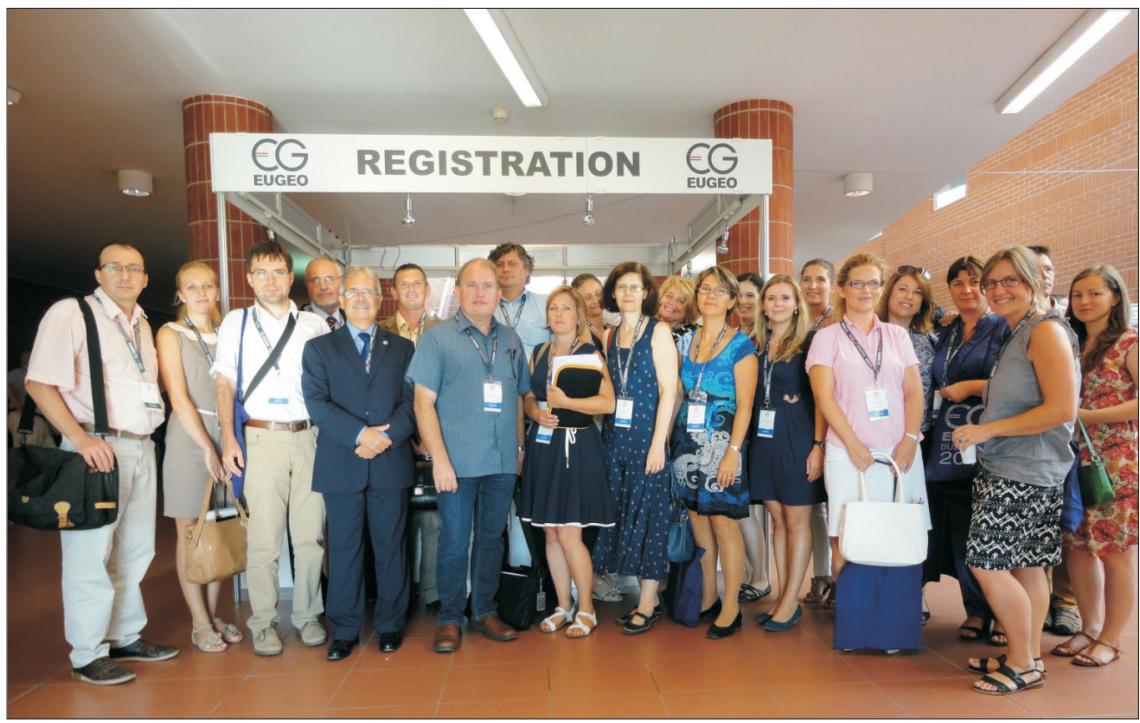

Photo 1. Participants of EUGEO 2015 Congress (Budapest) in the „Changing world, changing human mobilities: global convergence and divergence" session 
man spatial mobility in general. Today, the 150 members from 50 countries hold their annual scientific meetings at different locales throughout the world to present research and deliberate about a wide range of issues in numerous conference sessions focusing on a trans-disciplinary understanding of spatial mobilities.

In 2015, the EUGEO Congress in Budapest hosted the meetings of the IGU GLOBILITY Working Group. Scholars from a wide range of countries presented some 35 papers on many aspects of human mobility and global convergence in a changing world. The papers in this issue reflect some of the primary themes presented and discussed at the EUGEO Congress, such as the 'brain-drain', retirement migration, labour migration, return migration, the push and pull factors of international refugees coming to Europe, transportation innovations, tourism, crossborder economics and collaboration, debordering processes and 'Europeanisation'.

The paper by Lados and Hegedús in this theme issue deals with Hungarian return migration and the effects of identity change through the migratory process. The authors examine the post-return migration experiences of Hungarians who had gained significant experience, skills and assets abroad and those who had not. Higher-skilled returnees faced fewer socio-economic obstacles to reintegrating into Hungarian life, while those who had gained fewer skills were less content with their life back in the homeland. As such, low-skilled migrants appear more likely to re-emigrate abroad in the future than those who are more satisfied with their renewed life in Hungary.

Montanari and PAluzzi examine the role of 'Europeanisation' in increasing people's relocation from various EU countries to Italy. Their regional approach to assessing the spatial patterns and concentrations of European migration to Italy considered the influential variables of labour needs, age, nationality and tourist behaviour, including amenity migration. Gallo and Staniscia used a similar spatial clustering and mapping approach to examine the out-migration of Italian youth to other EU countries and the possible reasons for such patterns. They argue that the emigration of large numbers of young people in search of economic progress, adventure and lifestyle change may destabilize the social and economic sustainability of the countries and regions of origin. Similarly, SisKa-SzILAsI, KóRóDI and VADNAI examine the socio-spatial manifestations of Hungarian out-migration to other parts of Europe and North America. Their work highlights many of the socio-economic push factors in Hungary that cause people to emigrate, as well as the pull factors in destination countries that draw Hungarians therework, already emigrated friends and relatives, and perceptions of a more stable future.

Also examining migration patterns, Kocsis and his colleagues take a meta-European perspective in surveying the historical geography of migration patterns and their causes from Europe, to Europe, and within Europe. In particular, they look at the demographic implications of these mobility trends and provide a spatio-temporal analysis of recent and current patterns. The authors provide valuable insight into the current trend in mass migration to Europe from the Middle East, Africa and Asia, and the concrete sense of hopelessness, despair and persecution that overshadow these contemporary movement patterns more so than the more socio-economic tendencies of past generations.

In their study of ride sharing in Hungary, BÁLINT and TRócsáNYI touch on many sociospatial aspects of human mobility. Ride sharing is an increasingly important part of the new sharing economy (Heo, C.Y. 2016) and has major implications for employment commuting, commerce, and tourism. The authors examine price sensitivity, settlement size/hierarchy and critical mass of passengers and drivers, as well as demographics and education levels, in mapping the spatial configurations of ride sharing. While most of their data were confined to Hungary, their work also illustrated the potential of ride sharing to become a key part of the sharing economy for international travel as well.

In their study of worker and retiree migrants in Spain, Parreño-Castellano and 
Domínguez-Mujica investigate the multifarious trends associated with these forms of human mobility. Among other things, they focus on pensioners who had worked previously in Spain and remained there to spend their retirement years and the reasons for this behaviour. Many of these 'lifestyle immigrants' had worked in tourism and other services, including owning their own businesses, and had decided to remain in Spain's busiest coastal tourism regions after retirement for quality-of-life and socialisation reasons.

The treatise by Gellér-LukÁcs, TöTtös and ILLÉs speculates on the implications of the freedom of movement between the United Kingdom and the rest of the EU following the BREXIT vote of June 23, 2016. Taking a futuristic, scenarios-based approach, ILLÉS looks at the immigration policy portions of the initial negotiation documents and tries to predict some of the likely outcomes of the UK's departure. His examination of the current situation underscores the potential repercussions of the 're-bordering' process that has become quite evident in others parts of Europe and North America.

These 8 papers represent a sustained effort to understand human mobility in an increasingly 'borderless' Europe. Today, more than ever, geographers must continue to play a key role in understanding the causes, effects and manifestations of different types of migration and other mobility patterns and paradigms. This is especially the case in light of forecasts that Europe's share of international tourist arrivals compared to other regions will decline in the future while its position as a foremost destination for refugees and other immigrants will continue to swell (OECD 2016, UNWTO 2016). Because of Europe's current refugee crisis and migration predicament, we have seen the beginnings of the re-bordering of a continent that had until 2014 been an example of how a multi-nation region can de-border itself to facilitate freer human mobility (WiLson, T.M. and Donnan, H. 2012). Only time will tell how current geopolitical trends will affect future human mobilities in Europe.

\section{REFERENCES}

Andrijasevic, R. and Sacchetto, D. 2016. From labour migration to labour mobility? The return of the multinational worker in Europe. Transfer: European Review of Labour and Research 22. (2): 219-231.

Coles, T.E. and Тімотну, D.J. eds. 2004. Tourism, Diasporas and Space. London, Routledge.

Etzo, I., Massidda, C. and Piras, R. 2014. Migration and outbound tourism: Evidence from Italy. Annals of Tourism Research 48. 235-249.

Gosnell, H. and Abrams, J. 2011. Amenity migration: diverse conceptualizations of drivers, socioeconomic dimensions, and emerging challenges. GeoJournal 76. (4): 303-322.

Hall, C.M. and Williams, A. eds. 2002. Tourism and Migration: New Relationships between Production and Consumption. Dordrecht, Springer.

Heo, C.Y. 2016. Sharing economy and prospects in tourism research. Annals of Tourism Research 58. 166-170.

ILLÉs, S. 2015. Circular human mobility in Hungary. Migration Letters 12. (2): 152-161.

Illés, S. and Michalkó, G. 2008. Relationships between international tourism and migration in Hungary: Tourism flows and foreign property ownership. Tourism Geographies 10. (1): 98-118.

Lew, A.A., Hall, C.M. and Tiмотнy, D.J. 2015. World Regional Geography: Human Mobilities, Tourism Destinations, Sustainable Environments. $2^{\text {nd }}$ Edition. Dubuque, Iowa, Kendall-Hunt.

Merriman, P. 2009. Mobility. In International Encyclopaedia of Human Geography. Eds.: Kitchin, R. and Thrift, N., Amsterdam, Elsevier, 134-143.

Michalkó, G. and Tiмотнy, D.J. 2001. Cross-border shopping in Hungary: causes and effects. Visions in Leisure and Business 20. (1): 4-22.

OECD 2016. International Migration Outlook 2016. Paris, OECD Publishing.

StAeHELI, L.A. 2016. Globalization and the scales of citizenship. Geography Research Forum 19. 60-77.

Тıмотну, D.J. 2001. Tourism and Political Boundaries. London, Routledge.

Tiмотнy, D.J. and SAarinen, J. 2013. Cross-border co-operation and tourism in Europe. In Trends in European Tourism Planning and Organisation. Eds. Costa, C., Panyik, E. and Buhalis, D., Bristol, UK, Channel View, 64-74.

UNWTO 2016. Tourism Highlights 2016. Madrid, World Tourism Organization.

Wells, A. 2014. International student mobility: approaches, challenges and suggestions for further research. Procedia - Social and Behavioral Sciences 143. 19-24.

Wilson, T.M. and Donnan, H. 2012. Borders and border studies. In A Companion to Border Studies. Eds.: Wilson, T.M. and Donnan, H., Oxford, WileyBlackwell, 1-25. 